\title{
Actinoplanes liguriensis sp. nov. and Actinoplanes teichomyceticus sp. nov.
}

\author{
Joachim M. Wink, ${ }^{1}$ Reiner M. Kroppenstedt, ${ }^{2}$ Peter Schumann, ${ }^{2}$ \\ Gerhard Seibert ${ }^{1}$ and Erko Stackebrandt ${ }^{2}$ \\ ${ }^{1}$ Sanofi-Aventis Deutschland GmbH, SM\&A, Chemical Sciences, Natural Products, \\ 65926 Frankfurt am Main, Germany \\ ${ }^{2} \mathrm{DSMZ}$ - Deutsche Sammlung von Mikroorganismen und Zellkulturen GmbH, \\ Mascheroder Weg 1B, 38124 Braunschweig, Germany
}

Correspondence

Joachim M. Wink

Joachim.Wink@

sanofi-aventis.com

\begin{abstract}
The taxonomic status of 'Actinoplanes liguriae' A/6353 and 'Actinoplanes teichomyceticus' AB8327 was established by using a polyphasic approach. Strains A/6353 and AB8327 form distinct phylogenetic lineages in the $16 \mathrm{~S}$ rRNA gene tree of members of the genus Actinoplanes and are related moderately and closely to Actinoplanes rectilineatus and Actinoplanes cyaneus, respectively. Morphological, cultural and physiological properties indicated that strains A/6353 and AB8327 represent separate, novel species of the genus Actinoplanes, Actinoplanes liguriensis sp. nov. (type strain $\mathrm{A} / 6353^{\top}=\mathrm{FH} 2244^{\top}=\mathrm{DSM} 43865^{\top}=\mathrm{ATCC}^{\top} 31048^{\top}=\mathrm{BCRC} 12121^{\top}=\mathrm{CBS}$ $355.75^{\top}=\mathrm{IMSNU} 22127^{\top}=\mathrm{JCM} 3250^{\top}=\mathrm{KCTC} 9536^{\top}=\mathrm{KCC} \mathrm{A}-0250^{\top}=\mathrm{NBRC}$ $13997^{\top}=$ NCIMB $12636^{\top}=$ NRRL B $-16723^{\top}=$ SANK $62178^{\top}$ ) and Actinoplanes teichomyceticus sp. nov. (type strain AB8327 $=\mathrm{FH} 2149^{\top}=\mathrm{DSM} 43866^{\top}=\mathrm{ATCC} 31121^{\top}=\mathrm{BCRC}$ $12106^{\top}=$ FERM P-3462 ${ }^{\top}=$ IMSNU $20043^{\top}=$ IMET $9254^{\top}=\mathrm{JCM}^{\top} 3252^{\top}=\mathrm{KCC}^{\top}$ A$0252^{\top}=$ KCTC $9543^{\top}=$ NBRC $13999^{\top}=$ NCIMB $12640^{\top}=$ NRRL B-16726 ${ }^{\top}=$ SANK $\left.60479^{\top}\right)$.
\end{abstract}

In the course of a screening programme for inhibitors of peptidoglycan biosynthesis, a new antibiotic, $\mathrm{Ala}(O)$-actagardine, was isolated from strain A/6353, which was named 'Actinoplanes liguriae' in regard of the area in Italy, Liguria, where it had been isolated (Parenti \& Coronelli, 1979; Vertesy et al., 1999). Actinoplanes strain AB8327, the producer of the antibiotic gardimycin, was described and named by Parenti and coworkers as 'Actinoplanes teichomyceticus', referring to inhibition of cell-wall synthesis (Parenti et al., 1976). Neither name was validly published. In a study on the phylogenetic relationship of Actinoplanes species by comparative 16S rRNA gene sequencing by Tamura \& Hatano (2001), the two strains were included. In the resulting tree, derived by the neighbourjoining method, strains A/6353 and AB8327 were found to cluster within the radiation of Actinoplanes species, related sufficiently remotely from validly named species to warrant their description as novel species. This step is presented in this communication by providing sufficient taxonomic evidence to describe Actinoplanes liguriensis sp. nov. with the type strain $\mathrm{A} / 6353^{\mathrm{T}}$ and Actinoplanes teichomyceticus sp. nov. with the type strain $\mathrm{AB} 8327^{\mathrm{T}}$.

The strains under study were A/ $6353^{\mathrm{T}}\left(=\mathrm{DSM} 43865^{\mathrm{T}}\right.$ ), $\mathrm{AB} 8327^{\mathrm{T}}\left(=\mathrm{DSM} 43866^{\mathrm{T}}\right)$, Actinoplanes palleronii (DSM

The GenBank/EMBL/DDBJ accession numbers for the 16S rRNA gene sequences of strains DSM $43865^{\top}$ and DSM $43866^{\top}$ are AJ865471 and AJ865472, respectively.
$\left.43940^{\mathrm{T}}\right)$, Actinoplanes regularis (DSM $43151^{\mathrm{T}}$ ) and Actinoplanes rectilineatus (DSM $43808^{\mathrm{T}}$ ).

The morphological and physiological characteristics of the strains were studied after incubation for 10 days at $28^{\circ} \mathrm{C}$ on various media described by Shirling \& Gottlieb (1966): yeast extract/malt extract agar (ISP 2), oatmeal agar (ISP 3), inorganic salt/starch agar (ISP 4), glycerol/asparagine agar (ISP 5), peptone/yeast extract/iron agar (ISP 6) and tyrosine agar (ISP 7). For scanning electron microscopy, the strains were grown on different ISP media and prepared according to Grabley et al. (1992). Colours were determined according to the RAL colour code (RAL is the Deutsches Institut für Gütesicherung und Kennzeichnung e.V.-Reichsausschuß für Lieferbedingungen).

Utilization of carbohydrates was investigated on ISP medium 9 (Shirling \& Gottlieb, 1966) by using a microtitre-plate technique with 12-well plates. A fingerprint of enzymic activities was obtained by API 20E and API ZYM test strips (bioMérieux).

Analysis of the antimicrobial spectrum was performed as described by Williams et al. (1989). Bacterial strains were grown on Mueller-Hinton agar and fungal strains on Czapek Dox. For metabolite production, the Actinoplanes strains were incubated in four different media: a soybean meal medium, a starch medium and ISP media 2 and 3 for 7 days in shaking-flask cultures at $28^{\circ} \mathrm{C}$ and 180 r.p.m. 
After cultivation, the whole culture broth was extracted in methanol, evaporated to dryness and the residue was dissolved in water for antimicrobial testing.

Analysis of the whole-cell diaminopimelic acid isomers and the sugars was done by the method of Hasegawa et al. (1983). The phospholipids and menaquinones were analysed by the method of Minnikin et al. (1984). Analyses of whole-cell fatty acid pattern followed described methods using the MIDI system (Microbial ID, Inc.) (Kroppenstedt, 1985; Sasser, 1990).

Genomic DNA extraction, PCR-mediated amplification of the 16S rRNA gene and purification of PCR products were carried out as described previously (Rainey et al., 1996). The ae2 editor (Maidak et al., 2001) was used to align the almostcomplete $16 \mathrm{~S}$ rRNA gene sequences of strains $\mathrm{A} / 6353^{\mathrm{T}}$ and $\mathrm{AB} 8327^{\mathrm{T}}$ against the $16 \mathrm{~S}$ rRNA gene sequences of representatives of the main actinobacterial lineages and subsequently against members of the genus Actinoplanes. Pairwise evolutionary distances were computed by using the correction of Jukes \& Cantor (1969). A phylogenetic dendrogram was reconstructed from a distance matrix by using the treeing algorithm of DeSoete (1983). Automated ribotyping of the isolates was accomplished by using the RiboPrinter (Qualicon) system (Bruce, 1996) and PvuII as restriction enzyme for cutting the genomic DNA. The patterns were compared with those included in the DSMZ RiboPrint database.

Formation of characteristic sporangia was observed in both strains (Fig. 1). Fragmentation of substrate mycelium was not found. Strain $\mathrm{AB} 8327^{\mathrm{T}}$ formed a white aerial mycelium on ISP medium 2. The surface of the spores was smooth. Only rudimentary aerial mycelium was observed for strain $\mathrm{A} / 6353^{\mathrm{T}}$. The substrate mycelium of strain $\mathrm{A} / 6353^{\mathrm{T}}$ was yellow-orange (RAL 2000) on all tested ISP media. Strain $\mathrm{AB} 8327^{\mathrm{T}}$ formed pastel-yellow (RAL 1034) mycelium on ISP media 2, 3, 4 and 7 and beige (RAL 1001) mycelium on ISP media 5 and 6 . A yellow, soluble pigment was formed by strain $\mathrm{A} / 6353^{\mathrm{T}}$ on ISP media 4 and 5 and a red one on ISP 7. Strain $\mathrm{AB} 8327^{\mathrm{T}}$ produced a red, soluble pigment on ISP 5 and a brown one on ISP 6 and Suter medium with tyrosine (Table 1).

Glucose was the only carbohydrate that was used by both strains. Xylose, inositol and raffinose could not be assimilated by either of the strains, whereas $\mathrm{A} / 6353^{\mathrm{T}}$ could grow on rhamnose and $A B 8327^{\mathrm{T}}$ on arabinose, sucrose, mannose and fructose (Table 2).

Enzymic activities were analysed by using the API test systems API 20E and API ZYM (Table 3). Each strain showed a characteristic pattern with API $20 \mathrm{E}$ as well as with API ZYM. In the API $20 \mathrm{E}$ system, strains $\mathrm{A} / 6353^{\mathrm{T}}$ and $\mathrm{AB} 8327^{\mathrm{T}}$ showed urease activity, but lacked citrate utilization and indole production. In API ZYM tests, both strains were positive for alkaline phosphatase, esterase (C4), esterase lipase (C8) and phosphohydrolase, but negative
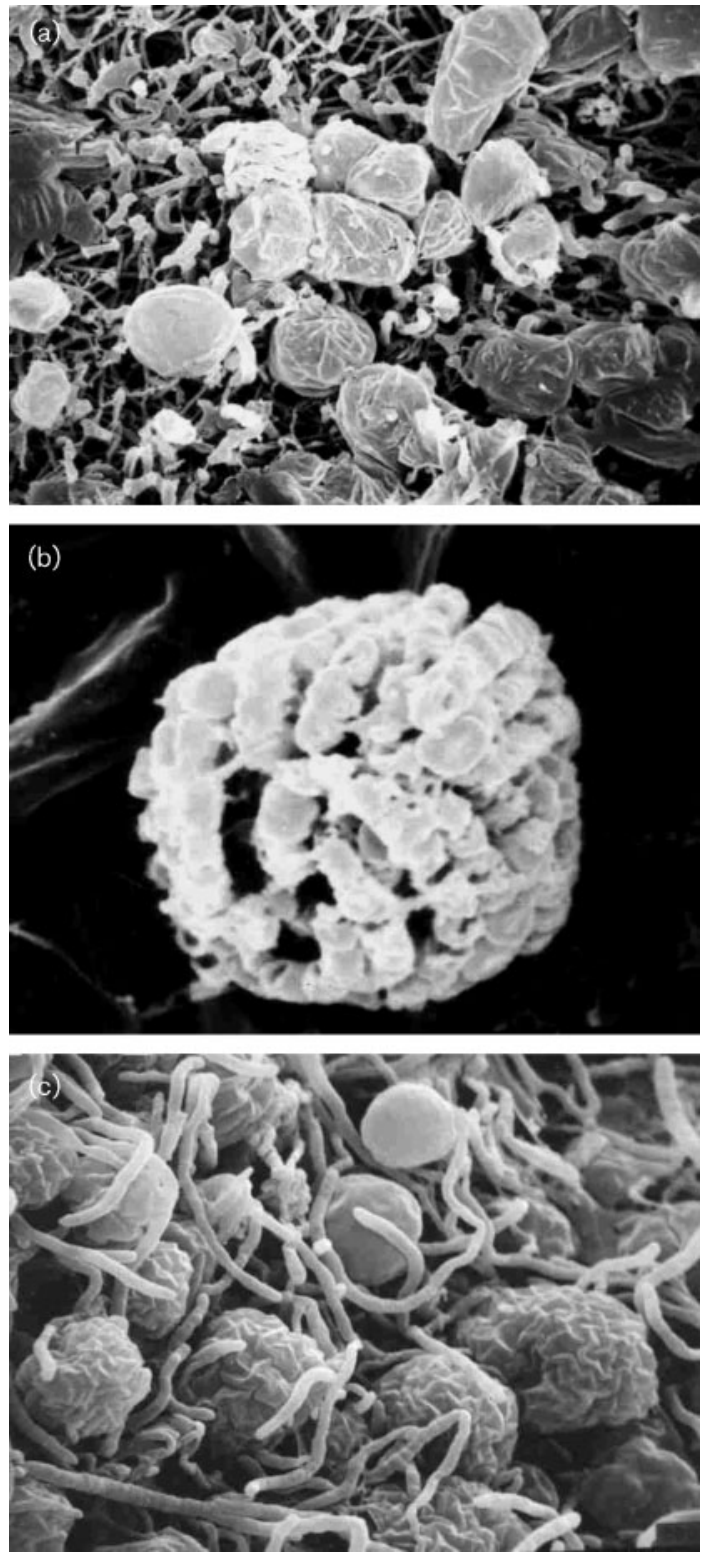

Fig. 1. Scanning electron micrograph displaying the morphology of strains $A / 6353^{\top}(a, b)$ and $A B 8327^{\top}$ (c). Cultivation was carried out on ISP medium 3 at $28^{\circ} \mathrm{C}$ for 14 days. (a) Sporophore and sporangia (magnification $\times 2000$ ). (b) Detail of spore chains by lack of sporangia envelope (magnification $\times 10000$ ). (c) Aerial mycelium and sporangia (magnification $\times 2000)$.

for lipase (C14), leucine arylamidase, valine arylamidase, cystine arylamidase and $\alpha$-fucosidase.

Whole-cell hydrolysates contained meso-diaminopimelic acid and the sugars xylose and arabinose. Mycolic acids were missing. The characteristic menaquinones were MK-9 $\left(\mathrm{H}_{4}\right)$ and MK-10 $\left(\mathrm{H}_{4}\right)$. In the polar lipid extract, the diagnostic phospholipid phosphatidylethanolamine could be detected, 
Table 1. Colonial characteristics of A. palleronii DSM $43940^{\top}$, A. rectilineatus DSM $43808^{\top}$, A. regularis DSM $43151^{\top}$, $\mathrm{A} / 6353^{\top}$ and $\mathrm{AB} 8327^{\top}$

Formation and colour of: SM, substrate mycelium; AM, aerial mycelium; SP, soluble exopigment.

\begin{tabular}{|c|c|c|c|c|c|}
\hline Culture medium & DSM $43940^{T}$ & DSM $43808^{T}$ & DSM $43151^{T}$ & $A / 6353^{T}$ & $\mathrm{AB8327^{ \textrm {T } }}$ \\
\hline ISP 2 & AM none & AM none & AM none & AM none & AM none \\
\hline \multirow[t]{3}{*}{ ISP 3} & SM beige & SM brown-orange & SM light orange & SM yellow-orange & SM pastel yellow \\
\hline & AM none & AM none & AM none & AM white & AM white \\
\hline & SP none & SP none & SP red & SP none & SP none \\
\hline \multirow{2}{*}{ ISP 4} & AM none & AM none & AM none & AM none & AM none \\
\hline & SP none & SP none & SP red & SP yellow & SP none \\
\hline \multirow[t]{3}{*}{ ISP 5} & SM beige & SM brown-orange & SM pure orange & SM yellow-orange & SM beige \\
\hline & AM none & AM none & AM none & AM none & AM none \\
\hline & SP none & SP none & SP red & SP yellow & SP red \\
\hline ISP 6 & SM beige & SM brown-orange & SM light orange & SM yellow-orange & SM beige \\
\hline \multirow{2}{*}{ ISP 7} & AM none & AM none & AM none & AM none & AM none \\
\hline & SP none & SP none & SP brown-red & SP red & SP none \\
\hline
\end{tabular}

but phosphatidylcholine and $\mathrm{N}$-acetylglucosamine were missing, i.e. phospholipid pattern type 2 according to Lechevalier et al. (1977). The fatty acid patterns were characteristic for Actinoplanes species, with major amounts of iso-C16:0, iso-C17:0, anteiso-C17:0, iso-C18:0 and $\mathrm{C} 18: 0$. A detailed listing of compounds with their quantities is indicated in the species descriptions.

Strains $\mathrm{A} / 6353^{\mathrm{T}}$ and $\mathrm{AB} 8327^{\mathrm{T}}$ share $97 \cdot 1 \% 16 \mathrm{~S}$ rRNA gene sequence similarity. Whilst $A$. teichomyceticus $\mathrm{AB} 8327^{\mathrm{T}}$ is related moderately to the type strain of $A$. rectilineatus, $A$. liguriensis $\mathrm{A} / 6353^{\mathrm{T}}$ shares $99 \cdot 3 \%$ similarity with the type strain of A. cyaneus. The binary DNA-DNA similarity value for the latter strain pair was $41.5 \%$ [mean of two values determined in $2 \times \mathrm{SSC}, 12 \%$ formamide at $70{ }^{\circ} \mathrm{C}$, according to Wink et al. (2003)]. 16S rRNA gene sequence similarity values with other type strains of the genus were $<98 \cdot 4 \%$. Fig. 2 displays the dendrogram of $16 \mathrm{~S}$ rRNA gene sequence similarities. Except for the branching of strains DSM $43865^{\mathrm{T}}$ $\left(\mathrm{A} / 6353^{\mathrm{T}}\right)$ and A. cyaneus DSM $46137^{\mathrm{T}}$, bootstrap values were $<80 \%$, hence they are not shown. Comparison with sequences deposited in public databases showed the similarity between strain $\mathrm{AB} 8327^{\mathrm{T}}$ and 'A. teichomyceticus' IFO 1999 (GenBank accession no. AB047513) to be $100 \%$, whilst the value between the two strains labelled 'A. liguriae' $\left(\mathrm{A} / 6353^{\mathrm{T}}\right.$ and IFO 13977, GenBank accession no. AB047497) was only $97 \cdot 3 \%$. In order to check the authenticity of strain $\mathrm{A} / 6353^{\mathrm{T}}$, originally obtained as ATCC 31048, we sequenced another culture of ATCC 31048 and confirmed its identity. Results of the sequencing

Table 2. Utilization of carbohydrates of $A$. palleronii DSM $43940^{\top}$, A. rectilineatus DSM $43808^{\top}, A$. regularis DSM $43151^{\top}, A / 6353^{\top}$ and $A B 8327^{\top}$

All strains utilize glucose.

\begin{tabular}{|c|c|c|c|c|c|}
\hline Carbohydrate & DSM $43940^{\mathrm{T}}$ & DSM $43808^{T}$ & DSM $43151^{T}$ & $\mathrm{~A} / 6353^{\mathrm{T}}$ & $\mathrm{AB8327}^{\mathrm{T}}$ \\
\hline Arabinose & - & + & + & - & + \\
\hline Sucrose & + & + & + & - & + \\
\hline Xylose & - & + & - & - & - \\
\hline Inositol & - & + & - & - & - \\
\hline Manitol & + & + & - & - & + \\
\hline Fructose & + & + & + & - & + \\
\hline Rhamnose & + & + & + & + & - \\
\hline Raffinose & - & + & - & - & - \\
\hline
\end{tabular}


Table 3. Enzymic activities of $A$. palleronii DSM $43940^{\top}, A$. rectilineatus DSM $43808^{\top}, A$. regularis DSM $43151^{\top}, \mathrm{A} / 6353^{\top}$ and $\mathrm{AB} 8327^{\top}$

All strains are positive for gelatinase and acid phosphatase; no strains produce $\mathrm{H}_{2} \mathrm{~S}$ or indole or show tryptophan deaminase, lipase (C14), valine arylamidase or $\alpha$-fucosidase activities.

\begin{tabular}{|c|c|c|c|c|c|}
\hline Physiological parameter & DSM $43940^{T}$ & DSM $43808^{T}$ & DSM $43151^{T}$ & $\mathrm{~A} / 6353^{\mathrm{T}}$ & $\mathrm{AB8327^{ \textrm {T } }}$ \\
\hline \multicolumn{6}{|l|}{ API 20E } \\
\hline$\beta$-Galactosidase & - & + & + & + & - \\
\hline Arginine dihydrolase & - & + & + & - & + \\
\hline Lysine decarboxylase & - & + & + & - & + \\
\hline Ornithine decarboxylase & - & - & + & - & + \\
\hline Citrate utilization & - & + & + & - & - \\
\hline Urease & - & + & + & + & + \\
\hline \multicolumn{6}{|l|}{ API ZYM } \\
\hline Alkaline phosphatase & + & + & - & + & + \\
\hline Esterase (C4) & + & + & - & + & + \\
\hline Esterase lipase (C8) & + & + & - & + & + \\
\hline Leucine arylamidase & + & + & - & - & - \\
\hline Cystine arylamidase & - & + & - & - & - \\
\hline Trypsin & - & + & - & + & - \\
\hline Chymotrypsin & - & + & + & + & - \\
\hline Naphthol-AS-BI-phosphohydrolase & - & + & - & + & + \\
\hline$\alpha$-Galactosidase & + & + & - & + & - \\
\hline$\beta$-Galactosidase & + & + & - & + & - \\
\hline$\beta$-Glucuronidase & - & - & - & + & - \\
\hline$\alpha$-Glucosidase & + & + & + & + & - \\
\hline$\beta$-Glucosidase & + & + & + & + & - \\
\hline$N$-Acetyl- $\beta$-glucoseaminidase & + & + & - & + & - \\
\hline$\alpha$-Mannosidase & - & + & - & + & - \\
\hline
\end{tabular}

studies were confirmed by RiboPrint analysis of strains $\mathrm{A} / 6353^{\mathrm{T}}, \mathrm{AB} 8327^{\mathrm{T}}$ and the closest phylogenetic relatives. Strains $\mathrm{A} / 6353^{\mathrm{T}}$ and $\mathrm{AB} 8327^{\mathrm{T}}$ showed unique RiboPrint

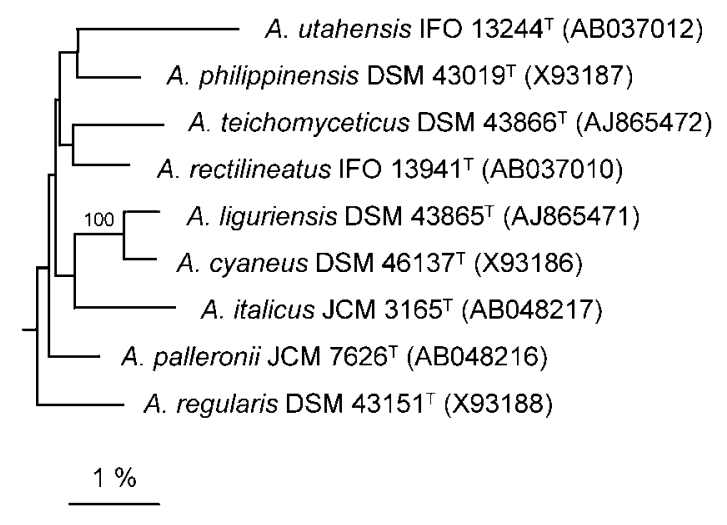

Fig. 2. $16 \mathrm{~S}$ rRNA gene dendrogram (DeSoete, 1983) displaying the phylogenetic position of novel members of the genus Actinoplanes and phylogenetically related members of the genus. Numbers indicate the percentage of bootstrap samplings, derived from 500 resamplings. More distantly related members of the genus served as a root. Numbers in parentheses are GenBank accession numbers for $16 \mathrm{~S}$ rRNA gene sequences. Bar, $1 \%$ sequence divergence. patterns that were clearly separated from the patterns of the other type strains (Fig. 3) and from those of all other Actinoplanes type strains (not shown). Based on the phylogenetic, chemotaxonomic and phenotypic results, it can be concluded that $\mathrm{A} / 6353^{\mathrm{T}}$ and $\mathrm{AB} 8327^{\mathrm{T}}$ represent the type strains of two novel species of the genus Actinoplanes and we therefore propose the names Actinoplanes liguriensis sp. nov. (type strain $\mathrm{A} / 6353^{\mathrm{T}}$ ) and Actinoplanes teichomyceticus sp. nov. (type strain $\mathrm{AB} 8327^{\mathrm{T}}$ ).

\section{Description of Actinoplanes liguriensis sp. nov.}

Actinoplanes liguriensis (li.gu.ri.en'sis. N.L. masc. adj. liguriensis pertaining to the Italian region of Liguria).

Cells are Gram-positive. Globose to oval sporangia are formed (see Fig. 1). Rudimentary sterile mycelium is formed only on ISP medium 6 . Colour of substrate mycelium is chrome yellow-orange (RAL 2000) on ISP media 2, 3, 4, 5, 6 and 7. A red, soluble pigment is formed on ISP medium 7. Colonial characteristics, carbohydrate-utilization pattern, enzyme activities and antimicrobial activities are indicated in Tables 1, 2, 3 and 4, respectively. Peptidoglycan contains meso-diaminopimelic acid; diagnostic sugars are xylose and arabinose; mycolic acids are absent; $\mathrm{MK}-9\left(\mathrm{H}_{4}\right)$ and $\mathrm{MK}-$ $10\left(\mathrm{H}_{4}\right)$ are the principal menaquinones; the major phospholipid is phosphatidylethanolamine. Major fatty acid methyl 


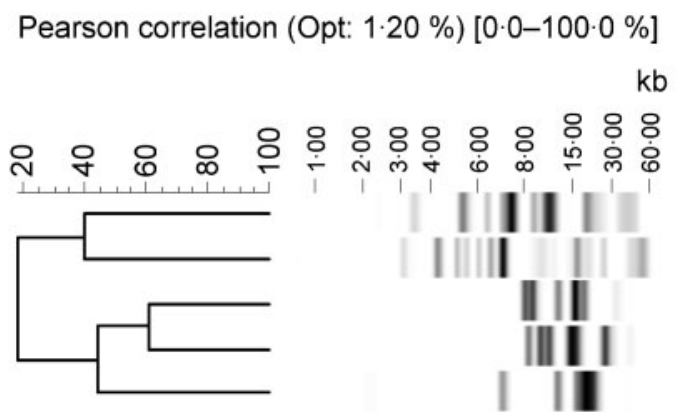

Actinoplanes palleronii DSM $43940^{\top}$

Actinoplanes cyaneus DSM $46137^{\top}$

Actinoplanes rectilineatus DSM $43808^{\top}$

Actinoplanes teichomyceticus DSM 43866 ${ }^{\top}$

Actinoplanes liguriensis DSM $43865^{\top}$

Fig. 3. Diversity of normalized Pvull ribotype patterns found within novel members of the genus Actinoplanes and their phylogenetic neighbours.

esters are $(>10 \%)$ : iso-C15:0 $(26 \cdot 1 \%)$, anteiso-C15:0 $(13 \cdot 1 \%)$, iso-C16:0 $(12 \cdot 1 \%)$, anteiso-C17:0 (11.0\%); others occur in smaller amounts $(\geqslant 1 \cdot 0 \%)$ : iso-C14:0 $(1 \cdot 7 \%), \mathrm{C} 14: 0(1 \cdot 8 \%), \mathrm{C} 15: 0(1 \cdot 5 \%), \mathrm{C} 16: 1(5 \cdot 80 \%)$, $\mathrm{C} 16: 0(6 \cdot 5 \%)$, iso-C17: 1 (1.9\%), anteiso-C17:0 (1.0\%), iso-C17:0 (3.0\%), cis-9-C17: 1 (2.2\%), cis-10-C17: 1 $(3 \cdot 3 \%), \mathrm{C} 17: 0(1 \cdot 2 \%)$, cis-9-C18:1 (2.9\%) and $\mathrm{C} 18: 0$ $(1 \cdot 5 \%)$. The antibiotics gardimycin and $\mathrm{Ala}(O)$-actagardine are produced.

The type strain is $\mathrm{A} / 6353^{\mathrm{T}} \quad\left(=\mathrm{FH} \quad 2244^{\mathrm{T}}=\mathrm{DSM}\right.$ $43865^{\mathrm{T}}=$ ATCC $31048^{\mathrm{T}}=$ BCRC $12121^{\mathrm{T}}=\mathrm{CBS} 355.75^{\mathrm{T}}=$ IMSNU $22127^{\mathrm{T}}=\mathrm{JCM} \quad 3250^{\mathrm{T}}=\mathrm{KCTC} \quad 9536^{\mathrm{T}}=\mathrm{KCC} \quad \mathrm{A}-$ $0250^{\mathrm{T}}=\mathrm{NBRC} \quad 13997^{\mathrm{T}}=\mathrm{NCIMB} \quad 12636^{\mathrm{T}}=\mathrm{NRRL} \quad \mathrm{B}-$ $16723^{\mathrm{T}}=$ SANK $62178^{\mathrm{T}}$ ). Isolated from Italian soil.

\section{Description of Actinoplanes teichomyceticus sp. nov.}

Actinoplanes teichomyceticus [tei.cho.my.ce'ti.cus. Gr. n. teichos wall; Gr. n. myces fungus; L. adj. suff. -icus belonging to; teichomyceticus belonging to a fungus cell wall (referring to inhibition of cell-wall synthesis by teichomycin, produced by the type strain)].

Cells are Gram-positive. Spherical to oval sporangia are formed (see Fig. 1). Long, sterile hyphae are formed on ISP media 2, 3, 4 and 5. Colour of substrate mycelium is pastel yellow (RAL 1034) on ISP media 2, 3, 4 and 7 and beige (RAL 1001) on ISP media 5 and 6. A red, soluble pigment is formed on ISP medium 5 and a brown one on ISP media 3 and 6. Colonial characteristics, carbohydrate-utilization pattern, enzyme activities and antimicrobial activities are indicated in Tables 1, 2, 3 and 4, respectively. Peptidoglycan contains meso-diaminopimelic acid; diagnostic sugars are xylose and arabinose; mycolic acids are absent; MK-9 $\left(\mathrm{H}_{4}\right)$ and $\mathrm{MK}-10\left(\mathrm{H}_{4}\right)$ are the principal menaquinones; the major phospholipid is phosphatidylethanolamine. Major fatty acid methyl esters are (>10\%): iso-C16:0 $(20 \cdot 7 \%)$, iso-C15:0 $(15 \cdot 1 \%)$, anteiso-C15:0 (8·8\%), anteiso-C17:0 (19.8\%); others occur in smaller amounts $(\geqslant 1 \cdot 0)$ : iso-C14:0 $(1 \cdot 0 \%), \mathrm{C} 15: 0(1 \cdot 1 \%)$, iso-C16:1 (1.6\%), cis-9-C16: 1 $(3 \cdot 4 \%), \mathrm{C} 16: 0(2 \cdot 5 \%)$, iso-C17: 1 (2.6\%), anteiso-C17: 1 $(2 \cdot 0 \%)$, iso-C17:0 $(3 \cdot 8 \%)$, cis-9-C17: $1(6 \cdot 7 \%), \mathrm{C} 17: 0$ (3.5\%), cis-9-C18:1 (4.3\%) and C18:0 (1.8\%). The antibiotics teichomycin A1 and A2 (renamed teicoplanin) are produced.

The type strain is $\mathrm{AB} 8327^{\mathrm{T}}\left(=\mathrm{FH} 2149^{\mathrm{T}}=\mathrm{DSM} 43866^{\mathrm{T}}=\right.$ ATCC $31121^{\mathrm{T}}=$ BCRC $12106^{\mathrm{T}}=$ FERM P-3462 ${ }^{\mathrm{T}}$ IMSNU $20043^{\mathrm{T}}=$ IMET $\quad 9254^{\mathrm{T}}=\mathrm{JCM} \quad 3252^{\mathrm{T}}=\mathrm{KCC} \quad \mathrm{A}-0252^{\mathrm{T}}=$ KCTC $9543^{\mathrm{T}}=\mathrm{NBRC} 13999^{\mathrm{T}}=\mathrm{NCIMB} \quad 12640^{\mathrm{T}}=\mathrm{NRRL}$ $\mathrm{B}-16726^{\mathrm{T}}=\mathrm{SANK} 60479^{\mathrm{T}}$ ). Isolated from Indian soil.

Table 4. Antimicrobial activities of $A$. palleronii DSM $43940^{\top}$, A. rectilineatus DSM $43808^{\top}, A$ regularis DSM $43151^{\top}$, $\mathrm{A} / 6353^{\top}$ and $\mathrm{AB832} 7^{\top}$

All strains showed no activity against the fungi Candida albicans, Saccharomyces cerevisiae and Aspergillus niger or the bacteria Escherichia coli and Pseudomonas aeruginosa.

\begin{tabular}{|c|c|c|c|c|c|}
\hline Test strain & DSM $43940^{T}$ & DSM $43808^{T}$ & DSM $43151^{T}$ & $\mathrm{~A} / 6353^{\mathrm{T}}$ & $\mathrm{AB8327^{ \textrm {T } }}$ \\
\hline Staphylococcus aureus & - & - & + & + & + \\
\hline Micrococcus luteus & + & - & + & - & - \\
\hline Bacillus subtilis & + & - & + & + & + \\
\hline
\end{tabular}




\section{References}

Bruce, J. (1996). Automated system rapidly identifies and characterizes microorganisms in food. Food Technol 50, 77-81.

DeSoete, G. (1983). A least squares algorithm for fitting additive trees to proximity data. Psychometrika 48, 621-626.

Grabley, S., Granzer, E., Hütter, K. \& 7 other authors (1992). Secondary metabolites by chemical screening. 8. Decarestrictines, a new family of inhibitors of cholesterol biosynthesis from Penicillium sp. I. Strain description, fermentation, isolation and properties. $J$ Antibiot 45, 56-65.

Hasegawa, T., Takizawa, M. \& Tanida, S. (1983). A rapid analysis for chemical grouping of aerobic actinomycetes. J Gen Appl Microbiol 29, 319-322.

Jukes, T. H. \& Cantor, C. R. (1969). Evolution of protein molecules. In Mammalian Protein Metabolism, pp. 21-132. Edited by H. N. Munro. New York: Academic Press.

Kroppenstedt, R. M. (1985). Fatty acid and menaquinone analysis of Actinomycetes and related organisms. In Chemical Methods in Bacterial Systematics (SAB Technical Series no. 20), pp. 173-199. Edited by M. Goodfellow \& D. E. Minnikin. London: Academic Press.

Lechevalier, M. P., De Bièvre, C. \& Lechevalier, H. (1977). Chemotaxonomy of aerobic actinomycetes: phospholipid composition. Biochem Syst Ecol 5, 249-260.

Maidak, B. L., Cole, J. R., Lilburn, T. G. \& 7 other authors (2001). The RDP-II (Ribosomal Database Project). Nucleic Acids Res 29, 173-174.

Minnikin, D. E., O’Donnell, A. G., Goodfellow, M., Alderson, G., Athalye, M., Schaal, K. \& Parlett, J. H. (1984). An integrated procedure for the extraction of isoprenoid quinones and polar lipids. J Microbiol Methods 2, 233-241.

Parenti, F. \& Coronelli, C. (1979). Members of the genus Actinoplanes and their antibiotics. Annu Rev Microbiol 33, 389-411.
Parenti, F., Pagani, H. \& Beretta, G. (1976). Gardimycin, a new antibiotic from Actinoplanes. I. Description of the producer strain and fermentation studies. J Antibiot 29, 501-506.

Rainey, F. A., Ward-Rainey, N., Kroppenstedt, R. M. \& Stackebrandt, E. (1996). The genus Nocardiopsis represents a phylogenetically coherent taxon and a distinct actinomycete lineage: proposal of Nocardiopsaceae fam. nov. Int J Syst Bacteriol 46, 1088-1092.

Sasser, M. (1990). Identification of Bacteria by Gas Chromatography of Cellular Fatty Acids (technical note no. 101). Newark, DE: MIDI Inc. (http://www.midi-inc.com/media/pdfs/TechNote_101.pdf).

Shirling, E. B. \& Gottlieb, D. (1966). Methods for characterization of Streptomyces species. Int J Syst Bacteriol 16, 313-340.

Tamura, T. \& Hatano, K. (2001). Phylogenetic analysis of the genus Actinoplanes and transfer of Actinoplanes minutisporangius Ruan et al. 1986 and 'Actinoplanes aurantiacus' to Cryptosporangium minutisporangium comb. nov. and Cryptosporangium aurantiacum sp. nov. Int J Syst Evol Microbiol 51, 2119-2125.

Vertesy, L., Aretz, W., Bonnefoy, A. \& 7 other authors (1999). $\mathrm{Ala}(O)$-actagardine, a new lantibiotic from cultures of Actinoplanes liguriae ATCC 31048. J Antibiot 52, 730-741.

Williams, S. T., Goodfellow, M. \& Alderson, G. (1989). Genus Streptomyces. In Bergey's Manual of Systematic Bacteriology, vol. 4, pp. 2452-2492. Edited by S. T. Williams, M. E. Sharpe \& J. G. Holt. Baltimore: Williams \& Wilkins.

Wink, J. M., Kroppenstedt, R. M., Ganguli, B. N., Nadkarni, S. R., Schumann, P., Seibert, G. \& Stackebrandt, E. (2003). Three new antibiotic producing species of the genus Amycolatopsis, Amycolatopsis balhimycina sp. nov., A. tolypomycina sp. nov., A. vancoresmycina sp. nov., and description of Amycolatopsis keratiniphila subsp. keratiniphila subsp. nov. and A. keratiniphila subsp. nogabecina subsp. nov. Syst Appl Microbiol 26, $38-46$. 